\title{
Suicídio: estudos fundamentais
}

\author{
Alexandrina M. A. da Silva Meleiro \\ Chei Tung Teng \\ Yuan Pang Wang \\ São Paulo: Segmento Farma, 2004
}

Zacaria Borge Ali Ramadam ${ }^{1}$
"Só existe um problema filosófico realmente sério: o suicídio. Julgar se a vida vale ou não vale a pena ser vivida é responder à pergunta fundamental da filosofia. O resto, se o mundo tem três dimensões, se o espírito tem nove ou doze categorias, vem depois".

A contundente abertura de "O mito de Sísifo", obra magistral de Albert Camus, bem resume o desafio e a tarefa gigantesca com que se defronta o estudioso do tema, já que a consciência da finitude e da morte, suas crenças e mitos, constituem o maior diferencial entre humanos e outros seres do planeta.

Esse livro, organizado e redigido por conceituados pesquisadores e professores de psiquiatria das melhores universidades brasileiras, desenvolve, em 12 capítulos, temas criteriosamente selecionados e revela uma notável maturidade científica e intelectual dos autores brasileiros, rivalizando com as melhores publicações internacionais. Em 215 páginas distribuem-se os seguintes assuntos: $\mathrm{O}$ comportamento suicida; Aspectos históricos do suicídio no Ocidente; Religião e comportamento suicida - a cultura da morte; Suicídio e teoria social; Aspectos psicológicos do suicídio; Epidemiologia do suicídio; Fatores de risco do suicídio; Neurobiologia do suicídio; Abordagem médica da tentativa de suicídio; Manejo das situações ligadas ao suicídio; O suicídio e sua prevenção; Suicídio assistido, eutanásia e cuidados paliativos.

Os capítulos foram redigidos em estilo agradável à leitura, despojados de criptogramas e cacoetes tecno-científicos, com informações copiosas e atualizadas, raramente encontradas em obras similares.

Além do rigor e do espírito crítico presentes em todos os capítulos, devese destacar o percurso pelas múltiplas vertentes doutrinárias, culturais e artísticas que interferem e se intercalam nos comportamentos suicidas. A obra extrapola o campo da psiquiatria, passando pela psicologia, antropologia, literatura, história, religião e outros aspectos adjacentes ao suicídio.

Cabe ressaltar a exaustiva e preciosa revisão bibliográfica que acompanha todos os capítulos, abrangendo todas as obras clássicas sobre o assunto, bem como os mais importantes e recentes artigos dos mais conceituados periódicos internacionais. O prefácio, redigido pelo Professor Wagner Farid Gattaz, Professor Titular de Psiquiatria da FMUSP, é um selo de garantia do valor da publicação, capaz de satisfazer os leitores mais exigentes e bem informados.

Nos últimos anos, raras são as monografias elaboradas com tanta abrangência e tal quantidade de informações. Pela consistência e seriedade, situa-se entre as melhores já publicadas nos países do Primeiro Mundo. Se tivesse uma versão em inglês, seria, certamente, referência internacional.

1 Professor-associado e chefe do Departamento de Psiquiatria do Hospital das Clínicas da Faculdade de Medicina da Universidade de São Paulo - (IPq-HC-FMUSP)

Endereço para correspondência: IPq-HC-FMUSP, Rua Ovídio Pires de Campos, 785, $3^{\circ}$ andar 05403-010 - email:zramadam@usp.br 